\title{
CHEMICAL ECOLOGY OF SHALLOW WATER OCTOCORALS. OCCURRENCE OF CEMBRANOLIDES IN PSEUDOPLEXAURA \\ AND EUNICEA.
}

by

LEON S. CIERESZKO ${ }^{1)}$

ABSTRACT

\begin{abstract}
Gorgonians of the genus Pseudoplexaura, from a variety of geographical locations, yield crassin acetate as the major cembranolide. The cembranolides found in Eunicea collected at different locations vary. Eunicin is found in Eunicea mammosa from Bimini, and from a number of other locations. Its position isomer Jeunicin, has been found in the Eunicea from Jamaica. Eunicea from Curacao yields an epimer ot eunicin, Cueunicin, while that from Puerto Rico yields Eupalmerin acetate, and Peunicin occurs in Eunicea collected off Panama. The cembranolides are toxic to various aquatic organisms. They inhibit ciliary action in the ciliate Tetrahymena pyriformis, and in the larvae of the nudibranch Phestilla sibogae.
\end{abstract}

Gorgonians or horny corals are coelenterates of the Class Anthozoa, Subclass Octocorallia, or Alcyonaria, Order Gorgonacea. They are prominent members of the sessile shallow water coral reef fauna in the Caribbean. They have few predators and hold their own in the competition for "space" on solid substrate in coral reef areas. I feel that the success of gorgonians against predation and against overgrowth by competing organisms is in part due to the secretion of defense substances (CIERESZKO 1960, 1973). These include diterpenoid compounds related to cembrene, a diterpene with a 14-membered ring.

The cembranolides are of ecological significance as they are toxic to a variety of organisms and inhibit ciliary motion (CIERESZKO 1962; PERKINS 1970, 1973, 1974). HADFIELD of Kewalo Marine Laboratory, University of Hawaii (personal communication), reports that in larvae of the nudibranch Phestilla sibogae velar cilia begin to disappear immediately when exposed to $10 \mathrm{ppm}$ eunicin (II) in sea water; all larvae are dead in $24 \mathrm{hr}$. If exposed to this concentration for as brief a period as 15 minutes and then transferred back to clean sea water, most larvae still died within the following 48 hrs. When exposed to 5 ppm of peunicin (VI), larvae stop swimming within 10 minutes but continue to live for at least 16 hours; after 24 hours larvae are dead and disintegrating:

1) Chemistry Department, the University of Oklahoma, Norman, Oklahoma 73019, U.S.A. 


\section{LEON S. CIERESZKO}

However, disintegrating larvae are devoured by very active ciliate protozoa.

Some cembranolides have shown activity in the $\mathrm{KB}$ test, an in vitro assay using cultures of human carcinoma cells and in the PS test, an in vivo assay against P-388 lymphocytic leukemia (WEINHEIMER 1975).

I should like to comment on the occurrence and geographical distribution of the cembranolides in various species of Pseudoplexaura and Eunicea.

Crassin acetate I has been found to occur in all specimens of three species of Pseudoplexaura: $P$. porosa, $P$. wagenaari and $P$. flagellosa collected at Belize, Bermuda, Bimini, Curacao, Florida, Grand Cayman, Jamaica, Puerto Rico, San Andres Isla (Colombia), St. Thomas and St. Croix (U. S. Virgin Islands), and St. Vincent.

Specimens of Eunicea mammosa and E. succinea have yielded five other cembranolides depending upon their geographical origin. Eunicea mammosa from Bimini yielded eunicin II as did the same species collected at Ambergris Cay (Belize), at Isla Providencia (Colombia), St. Thomas, St. Vincent, and Grand Cayman. Eunicea from Jamaica, collected in 1960 yielded pure peunicin III, an isomer of eunicin. Later collections yielded both jeunicin and eunicin, with the eunicin more common in recent collections. Eunicea mammosa and E. succinea var. plantaginea collected in 1962 at Margot Fish Shoal near Miami, Florida, yielded still another lactone, later named eupalmerin acetate IV (REHM 1971, EALICK 1975). REHM (1971) found eupalmerin acetate in Eunicea palmeri BAYER collected near the Ragged Keys of Florida, but eunicin in the same species of Eunicea was collected further south, in the Florida Keys, near Molasses Key and Spanish Harbor. We have found the Eunicea succinea collected off La Parguera, Puerto Rico, to be the richest source of eupalmerin acetate.

Examination of Eunicea mammosa collected in Curacao led to the discovery of a second isomer of eunicin, cueunicin V, which occurs largely as the acetate (Gross 1974). Collection of specimens of $E$. succinea var. plantiginea off Isla Buenavista, near Portobelo, Panama, led to the discovery of still another cembranolide, "peunicin" IV

(CHANG 1977).

Cembranolides have been sought for and found in Indo-Pacific octocorals. TURSCH (1974) found lobophytolide VII in the soft coral Lobophytum cristagallio and sinulariolide VIII in the soft coral Sinularia flexibilis, both collected in Indonesia off Sewaru (Leti Island). Other cembrane derivatives have been found in the Pacific soft corals, Litophyton viridia (TURSCH 1975) and Nephthea sp. (SCHMITZ 1974).

The concentration of cembranolide in the octocorals is high. Pseudoplexaura usually contains at least $2 \%$ of its dry weight of crassin 
CHEMICAL ECOLOGY OF SHALLOW WATER OCTOCORALS
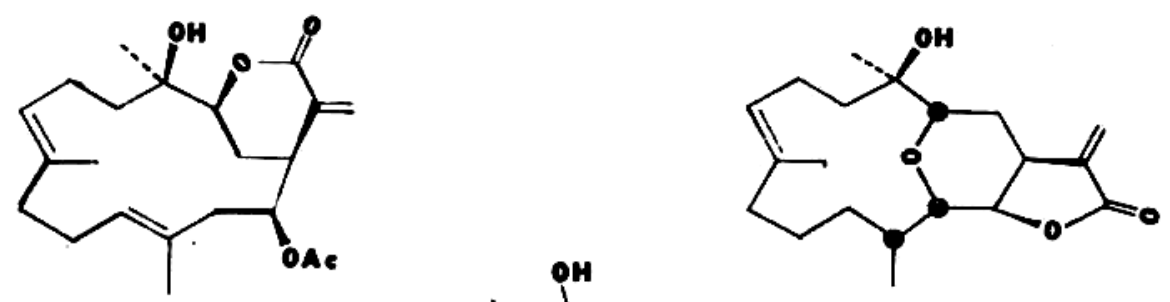

I

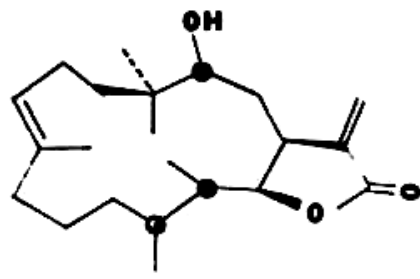

II

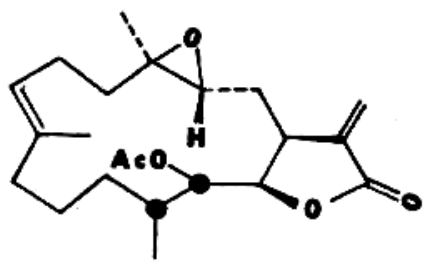

III

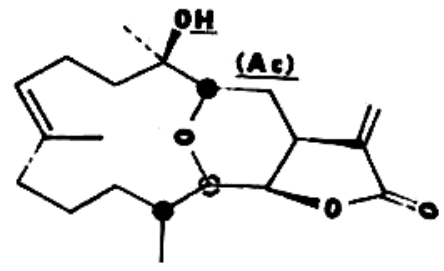

IV

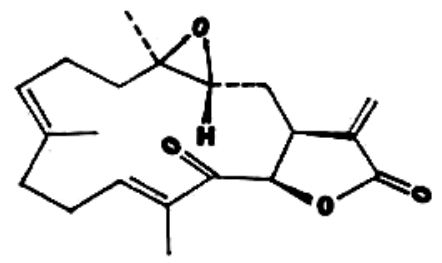

V

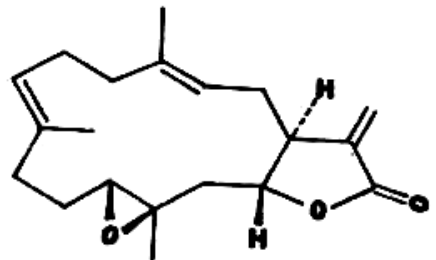

VII
VI

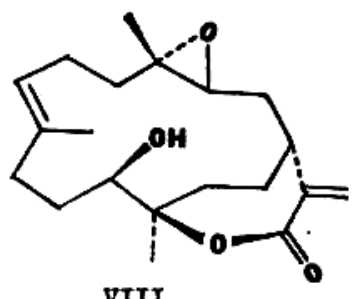

Leon S. Ciereszko 


\section{LEON S. CERESZKO}

acetate. Eunicea yield $0.5-2 \%$. of their dry weight of cembranolide. We have observed crystalline crassin acetate and eunicin in the brownish fluid expressed from Pseudoplexaura porosa and Eunicea mammosa by squeezing the live gorgonian. Crystalline crassin acetate has also been observed in the tissues of $P$. porosa by RICE (1970). I have prepared fairly pure crassin acetate by partially breaking up pieces of cortex from live P. porosa (Bermuda) in a Waring Blendor, straining off the coarse animal debris on a plastic kitchen sieve, allowing the denser calcareous spicules to settle and collecting the crystals from the suspension of finer materials on a nylon paint sieve which passes zooxanthellae.

I believe that the outer tissue fluids of the gorgonians are supersaturated with respect to the cembranolides and that these diterpenoids are being continously secreted. The cembranolides are odorless, but one can smell other terpenes peculiar to the gorgonians as soon as the animals are taken from the sea.

I should point out that PERKINS (1973) has produced Tetrahymena pyriformis resistant to crassin acetate, but this resistant strain is killed by eunicin or jeunicin.

The production of the variety of cembranolides in Eunicea from different locations may point to differences in the existing symbiotic algae (zooxanthellae). The sesquiterpene hydrocarbons found in Eunicea mammosa by YoungBLOOD (1969) vary with geographical origin. This is not the case with Pseudoplexaura prosa.

\section{PROCEDURE FOR PREPARATION OF CEMBRANOLIDES}

Gorgonians were collected by hand and drip-dried on a line during the sunny part of the day. Drying was completed in a stream of warm air from a blower. The dried ground gorgonian cortex was extracted in a continuous percolator-extractor (CIERESZKO 1966) with commercial n-hexane, changing the hexane in the boiling flask at intervals. On standing, partially concentrated extracts deposited insoluble material, often in crystalline form. The precipitates were washed with fresh hexane by decantation to remove some pigment and oil, and were then taken up in benzene. The benzene solution was poured into a column of dry Florisil (magnesium silicate adsorbent, Floridin Co.). Elution was carried out with benzene. Concentration of the benzene solutions from the column yielded crystalline solid which was recrystallized from benzene-hexane. The time of elution varied with the different cembranolides. The hydroxylated cembranolides eunicin, jeunicin, crassin acetate and cueinicin took considerably longer time than those lacking free hydroxyl groups, such as cueunicin acetate and eupalmerin acetate. 


\section{AKNOWLEDGEMENT}

Acknowledgement is made to the donors of the Petroleum Research Fund administered by the American Chemical Society, to the Office of Sea Grant NOAA, and to the National Institutes of Health for support of our marine studies. The use of field facilities of the Bermuda Biological Station, the American Museum of Natural History, the University of the West Indies, the University of Puerto Rico at Mayaguez, the Caraibisch Marien-Biologisch Instituut and the Smithsonian Tropical Research Institute made this survey possible.

\section{REFERENCES}

CHANG, C. Y. 1977. Ph.D. dissertation, The University of Oklahoma, Norman, Oklahoma, (in preparation)

CIERESZKO, L. S., D. H. SIFFORD and A. J. WEINHEIMER 1960. Chemistry of Coelenterates. I. Occurrence of terpenoid compounds in gorgonians. Ann. Acad. Sci. 90 : 917 - 919.

CIERESZKO, L. S. 1962. Chemistry of coelenterates. III. Occurrence of antimicrobial terpenoid compounds in the zooxanthellae of alcyonarians. Trans. N. Y. Acad. Sci. Sec. II. 24 : $502-503$.

CIERESZKO, L.S. 1966. A versatile continuous percolator-extractor. J. Chem. Educ. 43 : 252.

CIERESZKO, L.S. and T.K.B. KARNS 1973. Comparative biochemistry of coral reef coelenterates. In : Biology and Geology of Coral Reefs Vol. II Biology 1. Academic Press, New York: $183-203$.

Gross, R.A. 1974. I. Cueunicin and cueinicin acetate - two new cembranolides. II. Structure and pmr spectra of natural products. The association of high field vinyl methyl signals with trans double bond geometry in germacrene derivatives. III. New marine diterpenoids. Ph.D. dissertation. The University of Oklahoma.

PERKINS, " D.L. and L.S. CIERESZKO 1970. The effects of some diterpene lactones on Tetrahymena pyriformis. J. Protozool. Suppl. 17 : 20.

PERKINS, D.L. and L.S. CIERESZKO 1973. The environmental toxicity of crassin .acetate using Tetrahymena pyriformis as a model. Hydrobiologia $42: 77-84$.

PERKINS, D.L. and L.S. CIERESZKO 1974. Effect of a macrocyclic diterpene from tobacco on Tetrahymena pyriformis. Proc. Okla. Acad. Set $54: 34$ - 35.

REHM, S.J. 1971. I. Eupalmerin acetate : a marine epoxy cembranolide. II. Eunicea palmeri Bayer : an embivalent species. Ph.D. dissertation. The University of Oklahoma, Norman.

RICE, J.R., C. PAPASTEPHANOU and D.G. ANDERSON 1970. Isolation, localization and biosynthesis of crassin acetate in Pseucoplexaura porosa (Houttuyn). Biol. Bull. 138 : $334-343$.

SCHMITZ, F.J., D.J. VANDERAH and L.S. CIERESZKO 1974. Marine natural products: Nephthenol and epoxynephthenol acetate, cembrane derivatives from a soft coral. Chem. Comm. : 407 - 408.

TURSCH, B., J.C. BRAEKMAN and D. DALOZE 1975. Chemical studies of marine invertebrates - XIII 2-Hydroxy nephthenol, a novel cembrane diterpene from the soft coral Litophytonviridis (Coelenterate, Octocorallia, Alcyonacea). Bull. Soc. Chim. Belg. 84 : 767 - 774.

Tursch, B., J.C. Braekman, D. Daloze, M. Herin and R. Karlsson 1974. .Chemical studies of marine invertebrates. X. Lobophytolide, a new cembranolide diterpene from the soft coral Lobophytum cristagalli (Coelenterate, Octocorallia, Alcyonacea). Tetrahedron Lett. No. 43 : 3769 - 3772. 


\section{LEON S. CIERESZKO}

Tursch, B., J.C. Braekman, D. Daloze, M. Herin, R. Karlsson and D. Losman 1974. Chemical studies of marine invertebrates - XI. Sinulariolide, a new cembranolide diterpene from the soft coral Sinularia flexibilis (Coelenterate, Octocorallia, Alcyonacea). Tetrahedron 31 : $129-133$.

WEINHEIMER, A.J. and J.A. MATSON 1975. Crassin acetate, the principal antineoplastic agent in four gorgonians of the Pseudoplexaura genus. Lloydia 38 : 378 - 382. 